\title{
Implementation of Jigsaw Type Cooperative Learning Model to Improve Economics Learning Results
}

\author{
Rohmat $^{1}$, Luqman Hakim ${ }^{2}$, Norida Canda Sakti ${ }^{3}$
}

\begin{tabular}{l} 
ARTICLE INFO \\
\hline Article History: \\
Received 29.12.2018 \\
Received in revised form \\
04.03 .2019 \\
Accepted \\
Available online 01.07 .2019
\end{tabular}

INTRODUCTION

Education is a conscious effort to grow the potential of human resources. As stated in Undang-undang Republik Indonesia No. 20 Tahun 2003 pasal 3, has outlined that national education aims to educate the nation from developing Indonesian people as a whole, namely human beings who believe and devote to God Almighty and have noble character, have knowledge and skills, physical and spiritual health, a strong personality and independent and sense of social and national responsibility. (UURI, 2003)

One indication of the achievement of the educational process is that good learning outcomes are achieved or students get above average scores. According to Sudjana, (2004: 22) learning outcomes are abilities possessed by students after receiving their learning experience.

According to W. Winkel (in the book Psychology of Teaching 1989: 82) Definition of learning outcomes is the success achieved by students, namely student achievement in schools that manifest in the form of numbers.

According to Sujanto (1996: 53) "the implementation of teaching is often only the teacher dictates and the students take notes, then the students memorize it the same as the sound of notes and have absolutely no relation to the understanding or changes in the actions of students".

These problems are in accordance with the results of the interviews conducted by researchers towards students of class X7 Senior High School 7 Surabaya, that students have difficulty in receiving economic lesson material provided by the teacher. Students are also embarrassed to ask teachers and friends. So that causes students not able to solve the problems given by the teacher. Learning is still conventional in one direction. In this learning the students also work on two activities, namely listening and taking notes. The predominant lecture learning method does not activate student learning. Circumstances like this make students who learn individually do not involve interaction, causing student boredom which results in low economic learning outcomes.( Djafar, 2001)

According to Budimansyah (2002: 7) "Learning methods are a method used by teachers in the teaching and learning process". Learning methods in the economic learning process are not necessarily suitable for each subject matter, so the teacher must be able to choose an appropriate learning method so that the process of interaction between the teacher and students occurs as desired. Then it is necessary to choose the right learning strategy, so that it can increase the active understanding and results of student economic learning. The teacher continues to try to compile and apply various varied strategies so that students are interested and enthusiastic in learning economics. Among them by applying cooperative learning models.

\footnotetext{
${ }^{1}$ Corresponding e-mail: rohmat.aufklarung@gmail.com ; orcid.org/0000-0002-0518-6858

${ }^{2}$ Corresponding e-mail: luqmanhakim@unesa.ac.id; orcid.org/0000-0002-4662-4113

${ }_{3}$ Corresponding e-mail: noridacanda unesa acid; orcid

Corresponding e-mail: noridacanda@unesa.ac.id ; orcid.org/0000-0002-5805-2466

Student of Economics Education, Graduate Program of Surabaya State University
Lecturer of Economics Education, Graduate Program of Surabaya State University
} 
In the cooperative learning model the teacher conveys the learning objectives and motivates students and the teacher presents information through media or learning resources. Based on research conducted by Janah (2019), student learning outcomes in the experimental class 1 with cooperative learning models have a smaller average value which is equal to 74.75 compared to the learning outcomes of experimental class 2 students with inquiry learning models with an average value of 77.00. This attracted the interest of researchers to apply the jigsaw type cooperative learning model to improve learning outcomes.

According to Zaini (2002: 56-57) "Learning with the Jigsaw Method" is an interesting strategy to use if the material to be studied can be divided into several parts and parts of the method do not have to be sequential, after the material is divided students are grouped into several groups and each the group discussed the material, after each group sent its members to another group to convey what they learned from the group ". With this Jigsaw Method ordinary students help each other in solving the material discussed.

The advantages of the Jigsaw method According to Ibrahim, et al (2003: 120-121) that can develop better behavior and relationships between students and can develop students' academic abilities. Students learn more from their friends in learning than from the teacher. In accordance with these problems, the authors are interested in conducting research with the title of Implementation Of Jigsaw Type Cooperative Learning Model To Improve Economic Learning Results.

Based on the introduction, the hypothesis of this study is presumed that the application of the Jigsaw type cooperative learning model can improve the learning outcomes of Economics subjects. The purpose of this study was to find out the application of Jigsaw type cooperative learning to improve the learning outcomes of economic subjects in class X7 Senior High School 7 Surabaya in the Jigsaw cooperative learning cycle.

\section{METHOD}

This research is a classroom action research. The research subjects were students in class X7 Senior High School 7 Surabaya, which numbered 36 students, consisting of 19 men and 17 women. This study focused on the process of applying the Jigsaw type cooperative learning model to improving the learning outcomes of Economics subjects.

The classroom action research was carried out in three cycles with three meetings using the Jigsaw cooperative learning model. Each cycle consists of four stages, namely planning, implementation, observation, and reflection (Aqib, 2006)

According to Arikunto (2006: 16-20) the classroom action research model is: "Broadly speaking there are four stages that must be passed, namely (1) planning, (2) implementation, (3) observation, (4) reflection".

Before the planning stage, it is necessary to identify problems. The results of preliminary observations show that the learning outcomes of economic subjects in the class are still low. After formulating the problem, the researcher then planned the implementation of the Jigsaw type cooperative learning model. The thing that needs to be prepared to overcome this problem is the making of learning instruments. The instruments are in the form of Learning Implementation Plans (RPP), student worksheets, teacher and student activity observation sheets and final cycle evaluation questions or post test questions.

learning is carried out in accordance with the planned implementation of learning previously prepared. The material learned is different in each cycle. Every end of the cycle is carried out reflection and evaluation. Reflection is to review all activities that have been carried out on Jigsaw type cooperative learning. The results of the reflection are then used to determine the extent to which the action reaches the target. Evaluation results are used to plan improvements in the next cycle. Systematically classroom action research is carried out as shown in Figure 1.

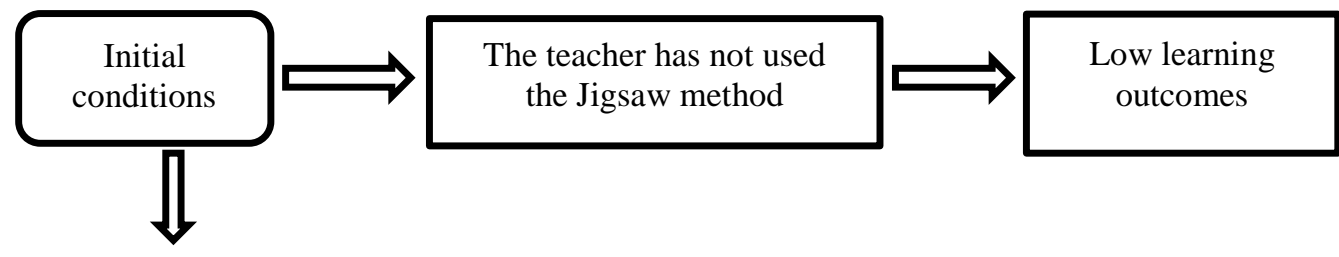




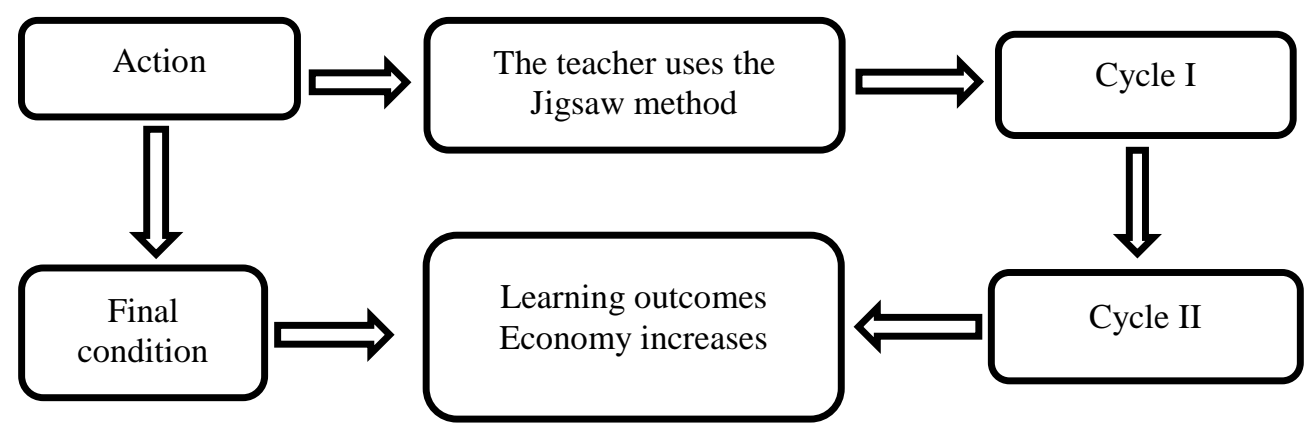

Figure 1. Thinking Framework

Data analysis in this study is descriptive qualitative, namely by analyzing the data of student development from cycle I to cycle II. Qualitative analysis techniques refer to the models of Miles and Huberman (1992) using interactive models that are carried out in 3 sequential components, namely data reduction, data presentation, and conclusion drawing.

Data reduction includes selecting data through summaries or brief descriptions and collecting data into broader patterns. Data presentation is carried out in order to organize data which is a systematic compilation of information from the results of data reduction, starting from the planning, implementation of actions of observation and reflection in each cycle.

Withdrawal of conclusions is an effort to search the meaning of data, record the order and classification of data. The collected data is presented systematically and needs to be given meaning. While the data obtained from test I, test II, test III and observation data with the assessment sheet were analyzed quantitatively. Comparison between class average values and standard deviation between test I, test II, and test III is used to determine an increase in value. If the class average value in test III is greater than test I and test II and standard deviation in test III is smaller than test I and test II, then there is an increase in student learning outcomes with the use of the Jigsaw cooperative learning model. The indicator of achievement in this study is an increase in the learning outcomes of economic subjects achieving a grade of classical completeness equal to or more than 75 .

\section{RESULT}

In this section the researcher will explain the results of the study. This research was conducted in two cycles and each cycle consisted of four stages, namely planning, implementation, observation, and reflection. Explanation of research results related to the implementation of Classroom Action Research (CAR) is more emphasized in each cycle.

\section{Pre Test}

Before the Jigsaw type cooperative learning model was applied, students were first given a pre-test for the entire material. This pre test aims to determine the extent to which students master learning material. The pre test results showed that only 4 students completed from 36 students and 32 students did not complete with a class average value of 54.02. This shows that most students get a score of 75 and below, so that it can be said that learning completeness has not been achieved. because researchers are guided by indicators of achievement in research are learning outcomes achieve the value of classical completeness equal to or more than 75 .

After conducting the pre-test the researchers then evaluated the results of the pre-test and it was found that learning completeness had not been achieved, so researchers wanted to improve learning outcomes using the Jigsaw cooperative learning method.

\section{Cycle 1}

Teaching and learning activities using the Jigsaw cooperative learning method in the first cycle carried out four stages, namely planning, implementation, observation / observation, and reflection. Before teaching and learning activities begin, researchers prepare a Learning Implementation Plan (RPP), student 
worksheets, teacher and student activity observation sheets and final cycle evaluation questions or post test questions.

During the learning activities using the Jigsaw cooperative learning model the researcher made observations by filling in the teacher activity observation sheet, as follows.

Table 1. Observation Results of Class X7 Student Cycle 1 Activity

\begin{tabular}{|c|c|c|}
\hline No & ASPECTS OBSERVED & SCORE \\
\hline \multirow[t]{13}{*}{1} & LEARNING ACTIVITIES & \multirow{5}{*}{$\begin{array}{l}2 \\
2 \\
3\end{array}$} \\
\hline & A. Initial Activity / Introduction & \\
\hline & 1. Motivate students & \\
\hline & 2. Associating with previous material & \\
\hline & 3. Deliver the learning objectives & \\
\hline & 4. Core Activities & \\
\hline & a. Delivering the subject matter & 3 \\
\hline & b. Organizing students to learn & 2 \\
\hline & c. Guiding groups working and learning & 3 \\
\hline & d. Facilitating students in presenting presentation materials & 3 \\
\hline & e. Analyze and evaluate the presentation process & 2 \\
\hline & 5. Cover & \\
\hline & Give students the opportunity to ask about material that is not yet understood. & 3 \\
\hline 2 & TIME MANAGEMENT & 2 \\
\hline \multirow[t]{6}{*}{3} & CLASS SITUATION & \multirow{4}{*}{$\begin{array}{l}3 \\
2 \\
3\end{array}$} \\
\hline & A. Student-centered & \\
\hline & B. Enthusiastic students & \\
\hline & C. Enthusiastic teacher & \\
\hline & TOTAL & 33 \\
\hline & AVERAGE & 2.53 \\
\hline
\end{tabular}

Information :

Score: $1=$ not good

$$
2 \text { = good enough }
$$$$
3=\operatorname{good}
$$

Average score criteria:

$4=$ very good
$1.00-1.49=$ not good
$2.50-3.49=$ good
$1.50-2.49=$ good enough
$3.50-4.00=$ very good

From the observations it can be seen that the overall average value obtained by the teacher in managing learning using the Jigsaw cooperative learning model has an average score of 2.53 . With good criteria. This shows that the teacher has been able to manage learning well.

In addition to filling out the teacher's activity observation sheet, the researcher also filled out the student activity observation sheet. From the observations it is known that the average value of all student activities during the Jigsaw cooperative learning process is 2.5 so that it can be categorized as a good predicate.

Based on the results of the pre test that had not yet achieved mastery learning, the researcher conducted a post test at the end of the study aimed at assessing learning outcomes with learning outcomes indicators reaching the same or more than 75 classical completeness scores. Post test results can be seen as follows:

Table 2. Results of Class X7 Student I Cycle Post Test

\begin{tabular}{|c|c|c|c|c|c|}
\hline $\begin{array}{c}\text { No } \\
\text { Student }\end{array}$ & $\begin{array}{c}\text { Score } \\
\text { Post test } \mathbf{1}\end{array}$ & GRADUATION \\
\hline 1 & 85 & Graduate \\
\hline 2 & 71 & Not Graduate \\
\hline 3 & 82 & Graduate \\
\hline 4 & 96 & Graduate \\
\hline 5 & 71 & Not Graduate & $\begin{array}{c}\text { No } \\
\text { Student }\end{array}$ & $\begin{array}{c}\text { Score } \\
\text { Post test } \mathbf{1}\end{array}$ & GRADUATION \\
\hline 19 & 75 & Graduate \\
\hline 20 & 84 & Graduate \\
\hline 21 & 78 & Graduate \\
\hline 22 & 82 & Graduate \\
\hline 23 & 87 & Graduate \\
\cline { 1 - 4 }
\end{tabular}




\begin{tabular}{|c|c|c|}
\cline { 3 - 3 } 6 & 91 & Graduate \\
\hline 7 & 86 & Graduate \\
\hline 8 & 71 & Not Graduate \\
\hline 9 & 75 & Graduate \\
\hline 10 & 88 & Graduate \\
\hline 11 & 86 & Graduate \\
\hline 12 & 89 & Graduate \\
\hline 13 & 86 & Graduate \\
\hline 14 & 96 & Graduate \\
\hline 15 & 98 & Graduate \\
\hline 16 & 82 & Graduate \\
\hline 17 & 71 & Not Graduate \\
\hline 18 & 84 & Graduate \\
\hline
\end{tabular}

\begin{tabular}{|c|c|c|}
\cline { 3 - 3 } 24 & 91 & Graduate \\
\hline 25 & 80 & Graduate \\
\hline 26 & 86 & Graduate \\
\hline 27 & 96 & Graduate \\
\hline 28 & 75 & Graduate \\
\hline 29 & 86 & Graduate \\
\hline 30 & 80 & Graduate \\
\hline 31 & 75 & Graduate \\
\hline 32 & 80 & Graduate \\
\hline 33 & 74 & Not Graduate \\
\hline 34 & 87 & Graduate \\
\hline 35 & 86 & Graduate \\
\hline 36 & 100 & Graduate \\
\hline$\Sigma$ & 3010 & \\
\hline
\end{tabular}

Based on the table above it can be seen the number of students who completed a total of 31 students (86.11\%) while the incomplete number of 5 students (13.89\%) with the highest value 100, the lowest value 71 , and the average value 83.61. Thus in learning in the cycle 1 of class X7 students of the Middle School of 7th Surabaya have not yet finished $100 \%$. So it needs to be continued to cycle 2 learning.

\section{Cycle 2}

Based on the results in cycle 1 which have not been completed, the teaching and learning activities using the Jigsaw cooperative learning method are continued to cycle 2 with the same steps with the first cycle, namely planning, implementation, observation / observation, and reflection. Before teaching and learning activities begin, researchers prepare a Learning Implementation Plan (RPP), student worksheets, teacher and student activity observation sheets and final cycle evaluation questions or post test questions.

The results of the observation of the teacher's ability to manage teaching and learning activities using the jigsaw cooperative learning model In the second cycle can be seen in the table as follows:

Table 3. Observation Results of Class X7 Student 2 Cycle Teacher Activity

\begin{tabular}{|c|c|c|}
\hline No & ASPECTS OBSERVED & SCORE \\
\hline \multirow[t]{13}{*}{1} & LEARNING ACTIVITIES & \multirow{5}{*}{$\begin{array}{l}2 \\
3 \\
4\end{array}$} \\
\hline & A. Initial Activity / Introduction & \\
\hline & 1. Motivate students & \\
\hline & 2. Associating with previous material & \\
\hline & 3. Deliver the learning objectives & \\
\hline & 4. Core Activities & \\
\hline & a. Delivering the subject matter & 3 \\
\hline & b. Organizing students to learn & 3 \\
\hline & c. Guiding groups working and learning & 3 \\
\hline & d. Facilitating students in presenting presentation materials & 4 \\
\hline & e. Analyze and evaluate the presentation process & 3 \\
\hline & 5. Cover & \\
\hline & Give students the opportunity to ask about material that is not yet understood. & 3 \\
\hline 2 & TIME MANAGEMENT & 3 \\
\hline \multirow[t]{4}{*}{3} & CLASS SITUATION & \multirow[b]{2}{*}{3} \\
\hline & A. Student-centered & \\
\hline & B. Enthusiastic students & 3 \\
\hline & C. Enthusiastic teacher & 3 \\
\hline & TOTAL & 43 \\
\hline & AVERAGE & 3.58 \\
\hline
\end{tabular}

Information :

Score: $1=$ not good $\quad 3=\operatorname{good}$ 


$$
2=\text { good enough }
$$

Average score criteria:

$1.00-1.49=$ not good

$1.50-2.49=$ good enough

\section{$4=$ very good}

$$
\begin{aligned}
& 2.50-3.49=\text { good } \\
& 3.50-4.00=\text { very good }
\end{aligned}
$$

Based on table 3.3 observation of teacher activity during the learning process using the Jigsaw cooperative learning model gets an average value of 3.58 so that it falls into the very good category.

In addition to filling out the teacher's activity observation sheet, the researcher also filled out the student activity observation sheet. From the observations it is known that the average value of all student activities during the Jigsaw cooperative learning process is 3.2 so that it can be categorized as a good predicate.

Based on the post test results in cycle 1 which have not yet achieved mastery learning, the researcher conducted a post test again in cycle 2 at the end of learning aimed at assessing learning outcomes with learning outcomes indicators reaching the same or more than 75 classical completeness scores. following:

Table 4. Results of Class X7 Student 2 Cycle Post Test

\begin{tabular}{|c|c|c|}
\hline $\begin{array}{c}\text { No } \\
\text { Student }\end{array}$ & $\begin{array}{c}\text { Score } \\
\text { Post test 2 }\end{array}$ & GRADUATION \\
\hline 1 & 95 & Graduate \\
\hline 2 & 80 & Graduate \\
\hline 3 & 75 & Graduate \\
\hline 4 & 95 & Graduate \\
\hline 5 & 75 & Graduate \\
\hline 6 & 100 & Graduate \\
\hline 7 & 75 & Graduate \\
\hline 8 & 75 & Graduate \\
\hline 9 & 85 & Graduate \\
\hline 10 & 75 & Graduate \\
\hline 11 & 75 & Graduate \\
\hline 12 & 100 & Graduate \\
\hline 13 & 75 & Graduate \\
\hline 14 & 75 & Graduate \\
\hline 15 & 95 & Graduate \\
\hline 16 & 80 & Graduate \\
\hline 17 & 95 & Graduate \\
\hline 18 & 75 & Graduate \\
\hline
\end{tabular}

\begin{tabular}{|c|c|c|}
\hline $\begin{array}{c}\text { No } \\
\text { Student }\end{array}$ & $\begin{array}{c}\text { Score } \\
\text { Post test 2 }\end{array}$ & GRADUATION \\
\hline 19 & 85 & Graduate \\
\hline 20 & 80 & Graduate \\
\hline 21 & 80 & Graduate \\
\hline 22 & 80 & Graduate \\
\hline 23 & 100 & Graduate \\
\hline 24 & 85 & Graduate \\
\hline 25 & 100 & Graduate \\
\hline 26 & 95 & Graduate \\
\hline 27 & 85 & Graduate \\
\hline 28 & 75 & Graduate \\
\hline 29 & 75 & Graduate \\
\hline 30 & 75 & Graduate \\
\hline 31 & 85 & Graduate \\
\hline 32 & 75 & Graduate \\
\hline 33 & 80 & Graduate \\
\hline 34 & 100 & Graduate \\
\hline 35 & 75 & Graduate \\
\hline 36 & 100 & Graduate \\
\hline $\mathbf{2}$ & 3030 & \\
\hline
\end{tabular}

Based on table 3.4 above, it can be seen that 36 students completed all with the highest score of 100, the lowest score was 75, and the average value was 84.17. Thus in learning in the cycle of 2 students in class X7 Middle School of State 7 Surabaya finished $100 \%$. By already fulfilling classical completeness.

The Jigsaw type cooperative learning method in this study was conducted in two cycles because in the second cycle all students of class X 7 Senior High School 7 Surabaya had achieved completeness can be seen in the table below.

Table 5. Class X7 Student Completeness

\begin{tabular}{|c|l|c|c|c|}
\hline No. & \multicolumn{1}{|c|}{ Description } & Pre test & Pos test I & Pos test II \\
\hline 1 & The number of students & 36 & 36 & 36 \\
\hline 2 & The number of students is Graduate & 4 & 31 & 36 \\
\hline
\end{tabular}




\begin{tabular}{|c|l|c|c|c|}
\hline 3 & The number of students is not Graduate & 32 & 5 & 0 \\
\hline 4 & Percentage (\%) & 11,11 & 86,11 & 100 \\
\hline
\end{tabular}

Based on the method of data analysis regarding the results of the final test that students can be said to be complete if they get the same or more than 75, then the results of the post test can be seen in each cycle. In the first post test students were completed as many as 31 students from 36 students or $86.11 \%$. The second post test experienced an increase in students who completed 36 students or $100 \%$.

\section{DISCUSSION, CONCLUSION AND SUGGESTIONS}

Based on the pre-test carried out before Cooperative Type Jigsaw learning activities were carried out obtaining the results of 4 students who completed from 36 students and their students 32 students did not complete with a class average value of 54.02. Thus learning completeness has not been achieved, so researchers want to improve learning outcomes by using the Jigsaw cooperative learning method.

In the pre-test until the second cycle there was an increase in the number of students who completed it, this indicates that the application of the Type Jigsaw cooperative learning model can achieve student learning completeness. These results are supported by the results of a study conducted by Jumiyati at all (2015) with the title "the application of jigsaw learning models on economic subjects to student learning outcomes in high school" concluded that the results of the analysis showed student learning outcomes using the jigsaw learning model increased with student completeness in working on the post test reaching $100 \%$.

In addition, this research is also supported by research conducted by Rokhmah \& Subroto (2019) with the research title "Application of Cooperative Learning Jigsaw Type to Improve Learning Outcomes of Economic Introduction and Business" The results showed that student activity increased $9.52 \%$ from cycle I $76.19 \%$ to $85.71 \%$ in cycle II. Students classical completeness increased by $16.22 \%$ from cycle I $64.86 \%$ to $81.08 \%$ in cycle II. It shows that jigsaw type cooperative learning model can improve learning outcomes on introductory subjects of economics and business students of class X Accounting 3 SMK Sejahtera Surabaya.

In another study conducted by Rumiyatun (2012) entitled "Application of the Jigsaw Type Cooperative Learning Model to Improve Student Learning Outcomes in Social Sciences Economics Subjects". Conclude that the jigsaw cooperative learning model is effective in improving student learning outcomes in Social Sciences Economics subjects. Hertiavi (2010) entitled "the application of a jigsaw type cooperative learning model for improving problem solving skills of junior high school students" concluded that Jigsaw type cooperative learning can significantly improve student learning outcomes.

Based on the results of research and discussion, it can be concluded that the results of learning completeness of students of Class X 7 Senior High School 7 Surabaya achieved after using Cooperative Type Jigsaw learning methods on economic subjects have increased, from the first cycle to the number of students who passed 31 then rose to 36 students who graduated on cycle II. So that in cycle II all students graduate.

Suggestions in this study are the ability of the teacher to direct students into the learning atmosphere must be increased, namely by conveying learning objectives and the material to be delivered are expected to be more focused and not convoluted so that students are more motivated and better understand the material to be delivered. Teachers should be more skilled in organizing students when group formation and discussion so that the time for learning is more effective, teachers more socialize the Jigsaw type cooperative learning model so students do not have difficulty in following it.

This study has limitations that cannot be controlled by researchers, namely the sincerity of student learning when research is conducted is something that is beyond the reach of researchers to control it. And in this study it cannot be generalized because it is related to students in certain classes. That is, the solution to the problem given is only valid in that class.

\section{REFERENCES}

Aqib, Zainal. (2006). Penelitian Tindakan Kelas. Bandung: Yrama Widya 
Rohmat, Hakim,L. \& Sakti,N.C. (2019). Implementation of Jigsaw type cooperative learning model to improve economics learning results. International Journal of Educational Research Review, 4(3),350-357.

Arikunto, Suharsimi. (2002). Manajemen Penelitian Edisi Revisi. Jakarta : Bumi Aksara.

Budimansyah, Dasim. (2002). Model Pembelajaran dan Berbasis Portofolio. Bandung : PT. Genesindo.

Djafar, Tengku Zahara. (2001). Kontribusi Strategi Pembelajaran Terhadap Hasil Belajar. Padang: Fakultas Ilmu Pendidikan Universitas Negeri Padang.

Hertiavi, M. A., Langlang, \& H., Khanafiyah, S. (2010) “Penerapan Model Pembelajaran Kooperatif Tipe Jigsaw Untuk Peningkatan Kemampuan Pemecahan Masalah Siswa SMP". JOURNAL UNNES. ISSN: 1693-1246

Ibrahim, dkk. (2003). Perencanaan Pembelajaran. Bandung : PT. Remaja Rosdakarya.

Janah,I.I.N. \& Subroto,W.T. (2019). Comparison of cooperative learning models with inquiry on student learning outcomes. International Journal of Educational Research Review,4(2),58-62.

Jumiyati, Sastrawan, A., \& Sri Buwono, S. (2015) "Penerapan Model Pembelajaran Jigsaw Pada Mata Pelajaran Ekonomi Terhadap Hasil Belajar Siswa di SMA". Jurnal Pendidikan Ekonomi FKIP Untan, Pontianak.1-12.

Miles, B. Mathew, Huberman, M. (1992). Analisis Data Kualitatif Buku Sumber Tentang Metode-metode Baru. Jakarta: UIP.

UURI. (2003). Undang-Undang RI No 20 Tahun 2003 Tentang Sistem Pendidikan Nasional. Jakarta : CV. Eka Jaya.

Rokhmah, F. N., Subroto, W. T. (2019) “Application of Cooperative Learning Jigsaw Type to Improve Learning Outcomes of Economic Introduction and Business". International Journal of Educational Research Review. 4(2), 238-244.

Rumiyatun. (2012). "Penerapan Model Pembelajaran Kooperatif Tipe Jigsaw Untuk Meningkatkan Hasil Belajar Siswa Pada Mata Pelajaran IPS Ekonomi". Jurnal Pendidikan Ekonomi Dinamika Pendidikan.VII (1), $43-52$

Sudjana, Nana. (2004). Dasar-dasar Proses Belajar Mengajar. Bandung :Sinar Baru Algensido Offset

Sujanto, Agus. (1996). Psikologi Perkembangan. Jakarta: Rineka Cipta

Winkel, W.S. (1983). Psikologi Pengajaran . Jakarta: PT. Gramedia Widia Sarana Indonesia.

Zaini, Hisyam. (2002). Strategi Pembelajaran Kooperatif. Jakarta : Rineka Cipta. 